\title{
Is there a relationship between election outcomes and perceptions of personal economic well-being? A test using post-election economic expectations
}

\author{
Garrett Glasgow \\ University of California, Santa Barbara \\ Roberto A. Weber \\ Carnegie Mellon University
}

November 29, 2004

\begin{abstract}
Do individuals believe that an election victory by their favored candidate will improve their personal economic well-being? Previous work has either adopted an approach that is not well suited to determining this relationship, or ignored this question to focus on perceptions of macroeconomic conditions. In this paper we adopt a new approach that allows us to determine the relationship individuals perceive between elections and personal economic welfare, examining the relationship between vote choice, the election outcome, and post-election expectations for personal economic well-being. We find that economic individualism plays an important role in shaping the relationship individuals perceive between election outcomes and their personal economic well-being. Individuals who reject economic individualism do perceive a relationship, with those viewing an election outcome as favorable more optimistic in their expectations for personal economic well-being than those who view the election outcome as unfavorable. Conversely, election outcomes do not influence the expectations of economic individualists.
\end{abstract}

Thanks to Sean Gailmard, William Keech, John Patty, Kevin Quinn, Christina Fong, Jesse James DuPree, and seminar participants at Carnegie Mellon University for helpful comments, suggestions, and motivation. Thanks also to Jason Dana and Andrea Haupt for research assistance. 


\title{
Is there a relationship between election outcomes and perceptions of personal economic well-being? A test using post-election economic expectations
}

\begin{abstract}
Do individuals believe that an election victory by their favored candidate will improve their personal economic well-being? Previous work has either adopted an approach that is not well suited to determining this relationship, or ignored this question to focus on perceptions of macroeconomic conditions. In this paper we adopt a new approach that allows us to determine the relationship individuals perceive between elections and personal economic welfare, examining the relationship between vote choice, the election outcome, and post-election expectations for personal economic well-being. We find that economic individualism plays an important role in shaping the relationship individuals perceive between election outcomes and their personal economic well-being. Individuals who reject economic individualism do perceive a relationship, with those viewing an election outcome as favorable more optimistic in their expectations for personal economic well-being than those who view the election outcome as unfavorable. Conversely, election outcomes do not influence the expectations of economic individualists.
\end{abstract}




\section{Introduction}

Do individuals believe that an election victory by their favored candidate will improve their personal economic well-being? The answer to this question has implications for our understanding of voting behavior, electoral campaigns, and the formation of economic perceptions. However, despite a vast literature on the relationship between economics and politics, we are still unsure if individuals believe that the outcomes of national elections will influence their personal economic situation. This is because previous work has either adopted an approach that is not well suited to determining this relationship, or ignored this question to focus on perceptions of macroeconomic conditions. In this paper we adopt a new approach that allows us to examine the relationship individuals perceive between elections and personal economic welfare, examining the relationship between vote choice, the election outcome, and post-election expectations for personal economic well-being.

The dominant approach to studying the relationship between economic perceptions and elections is of the "economic voting" variety - examining the influence of economic perceptions on voting behavior or candidate popularity (Lewis-Beck and Paldam 2000, Norpoth et al. 1991). Most economic voting studies agree that voters rely on evaluations of the state of the national economy ("sociotropic" evaluations) rather than personal economic considerations ("pocketbook" or "egocentric" evaluations) when casting a vote (e.g., Kinder and Kiewiet 1981, Lewis-Beck 1988, Lewis-Beck and Paldam 2000). However, this does not prove that voters see no relationship between the candidates in an election and their own personal financial situation. Sociotropic voters may see a relationship between election outcomes and their personal economic well-being, yet only vote based only on what they believe is good for the country as a whole. Sociotropic voters may even be motivated by economic self-interest, viewing the state of the national economy as the best indication of whether an incumbent will 
produce economic conditions that benefit them personally. Thus, while studies of economic voting can tell us what economic information individuals use to cast a vote, they do not reveal the link individuals perceive between the candidates in elections and their personal economic welfare (Kinder and Kiewiet 1981, Kiewiet 1983).

While it is impossible to determine the relationship between election outcomes and perceptions of personal economic well-being in studies of economic voting, this is not the case when we consider post-election economic expectations. If individuals believe that an election victory by their favored candidate will improve their personal finances, then we would expect the outcome of the election to influence their expectations for the future. All else equal, individuals who believe the election outcome will influence their personal economic situation should be more optimistic about their future personal economic well-being after a favorable election outcome (when their favored candidate wins) than after an unfavorable election outcome (when their favored candidate loses). However, if individuals do not believe the election outcome will influence their personal finances, then perceptions of the election outcome should not influence their post-election expectations for personal economic well-being.

We test the link between elections and perceptions of personal economic well-being by using post-election survey data to examine the relationship between vote choice, election outcomes, and post-election expectations for personal economic well-being. We hypothesize that this relationship will be influenced by economic individualism, or adherence to the "ethic of self-reliance." Economic individualists believe that individuals are largely responsible for their own economic outcomes (Feldman 1982, Schlozman and Verba 1979, Sniderman and Brody 1977). While most studies that examine the influence of economic individualism focus on its effect on economic voting, we hypothesize here that economic individualism is also an important factor in shaping the relationship individuals see between election outcomes and 
their personal economic fortunes. We predict that election outcomes will have an effect on the expectations of those who reject economic individualism, with those viewing an election outcome as favorable more optimistic in their post-election expectations for personal economic well-being than those who view the election outcome as unfavorable. Conversely, we predict that election outcomes will not influence the post-election expectations of economic individualists.

Our study joins the small but growing body of work that examines the influence of political events and information on the formation of economic perceptions. Existing studies have generally focused on the formation of perceptions of macroeconomic indicators or the economy as a whole (e.g., Anderson et al. 2004, Conover et al. 1986, 1987, DeBoef and Kellstedt 2004, Duch et al. 2000, Haller and Norpoth 1994). Thus, examining how elections influence perceptions of personal economic well-being (and how this might vary with adherence to economic individualism) will not only help us determine the links individuals perceive between elections and personal economic conditions and further our understanding of the role of economic individualism, but will also contribute to our understanding of the formation of and heterogeneity in economic perceptions (Duch et al. 2000, Haller and Norpoth 1997, Hetherington 1996, Krause 1997). In addition, examining the relationship between voting, election outcomes, and national and personal economic expectations might also shed light on the underlying economic motives behind a vote choice, a possibility we explore in the conclusion to this paper.

In the following section we explain in more detail how perceptions of election outcomes and post-election expectations for personal economic well-being can be used to determine if individuals see a link between who holds political power and their own economic fortunes. We also explain how economic individualism is expected to moderate this relationship, and how considering this moderating influence allows us to overcome some of the methodological 
challenges that arise when examining perceptions of personal economic well-being. Section 3 tests for the influence of election outcomes on expectations using survey data from the 1994 German Bundestag (lower house) election. As hypothesized, we find that those who reject economic individualism perceive a relationship between the election outcome and their personal economic well-being, with those viewing the election outcome as favorable more optimistic in their expectations than those who view the election outcome as unfavorable. No relationship is apparent for economic individualists. Section 4 concludes.

\section{Elections, economic expectations, and economic in- dividualism}

We begin by describing what we can learn about the relationship individuals perceive between election outcomes and their personal economic well-being by using post-election economic expectations. We then discuss the role of economic individualism and some methodological obstacles.

\subsection{Election outcomes and expectations for personal economic well-being}

If individuals believe that an election victory by their favored candidate will improve their personal financial situation, this should be reflected in their post-election economic expectations - individuals should be more optimistic about their future personal finances after the election if the election outcome is a victory for their favored candidate than if the election outcome is a defeat. ${ }^{1}$ Thus, by examining the relationship between election outcomes and 
post-election expectations we can determine the relationship individuals perceive between elections and their personal economic well-being. We explain the logic behind our empirical test with the following simple model of economic expectation formation.

Let us assume that there are two candidates competing in an election ( $L$ and $R$ ), and individuals are able to form an opinion about the expected effect of a victory by each candidate on their future personal economic well-being. ${ }^{2}$ If the expected effect of candidate $L$ 's victory on personal economic well-being for a hypothetical individual is given by $\pi_{L}$, and the expected effect of candidate $R$ 's victory is given by $\pi_{R}$, then this individual's expectations for personal economic well-being after the election are given by:

$$
\begin{array}{ll}
E(P F)=\alpha+\pi_{L} & \text { if } \mathrm{L} \text { wins } \\
E(P F)=\alpha+\pi_{R} & \text { if } \mathrm{R} \text { wins }
\end{array}
$$

where $E(P F)$ is this individual's expectation for his or her personal financial situation in the future, and $\alpha$ represents influences on this individual's future personal financial situation that are not related to the election.

Suppose our hypothetical individual believed that an election victory by his or her favored candidate would improve future personal economic well-being, and this individual favored candidate $L$. This means that $\pi_{L}>\pi_{R}$, and the election outcome will influence post-election expectations for this individual, with this individual more optimistic about his or her future personal finances if candidate $L$ wins than if candidate $R$ wins. There are two reasons why we might observe a relationship between favorable election outcomes and an individual's post-election expectations for personal economic well-being. First, the election outcome 
will influence expectations if individuals are casting economically self-interested votes. An individual voting for candidate $L$ out of the belief that this will produce better personal economic welfare would thus have more optimistic post-election expectations if candidate $L$ wins than if candidate $R$ wins. Second, the election outcome will influence expectations even if individuals are not casting directly self-interested votes, but the factors they do use to determine their vote choice are positively correlated with the anticipated effect of a victory by their preferred candidate on their personal economic well-being.

If a favorable election outcome does not influence post-election expectations for personal economic well-being, then we know that neither of the above possible relationships holds. This may be for several possible reasons. For instance, it may be because individuals see no difference in the expected effects of potential election outcomes on their personal economic well-being $\left(\pi_{L}=\pi_{R}\right)$. Individuals could view the economic policies of the candidates as identical, or believe that election outcomes do not influence their personal financial situation $\left(\pi_{L}=\pi_{R}=0\right)$. It may also be that individuals see a difference in the influence of potential election outcomes on their personal economic well-being, but vote in a way completely unrelated to these perceptions - that is, they are just as likely to vote for candidate $L$ if they believe $\pi_{L}<\pi_{R}$ as when they believe $\pi_{L}>\pi_{R}$.

As the above discussion suggests, testing the relationship between election outcomes and expectations for personal economic well-being can be useful for understanding voters' economic motivations and perceptions. For instance, finding no relationship between a favorable election outcome and personal economic expectations would refute the possibility that voters are voting out of economic self-interest. On the other hand, finding a positive relationship would indicates that voters perceive at least some influence of election outcomes on their personal economic well-being. 
One concern when considering the relationship between economic and political perceptions as we do in our empirical test is endogeneity - while perceptions of economic conditions shape political preferences, these political preferences might in turn influence perceptions of economic conditions (Anderson et al. 2004, Palmer and Duch 2001, Sears and Lau 1983, Wlezien et al. 1997). Of particular relevance here, Anderson et al. (2004) find that individuals who voted for the winning party in the 1997 British election had more positive expectations about the general economy after the election than before the election, and attribute this finding to endogeneity. Two points are worth noting here. First, the "rational partisan model" of Alesina and Rosenthal (1995) predicts exactly this finding. The economic expectations of an individual before the election are given by:

$$
E(P F)=\alpha+P \pi_{L}+(1-P) \pi_{R}
$$

where $P$ is the probability that candidate $L$ wins the election. Unless $P$ is either 1 or 0 these pre-election expectations will differ from the post-election expectations given in Eqns. 1 and 2. For those who believe $\pi_{L}>\pi_{R}$, expectations will become more positive after the election if candidate $L$ wins, and more pessimistic if candidate $L$ loses. The election outcome will have the opposite effect for those who believe $\pi_{L}<\pi_{R}$. Thus, the differences between pre- and post-election expectations can be explained by differences in the expected effect of the candidates' economic policies and the resolution of uncertainty about the election winner after the election outcome is known. Second, the temporal difference between vote choice and post-election expectations means that we do not have a simultaneity problem - while previous vote choice can shape post-election economic expectations, these expectations cannot in turn influence previous vote choice. ${ }^{3}$ This is not to say that post-election expectations are not subject to partisan bias and other factors that concern those who study 
the formation of economic perceptions. However, our concern here is not whether individuals are forming accurate or unbiased economic expectations, but whether individuals see a relationship between election outcomes and their personal economic well-being at all.

\subsection{Economic individualism and methodological obstacles}

We hypothesize that whether an individual sees a relationship between election outcomes and personal economic well-being is influenced by belief in economic individualism. Most studies of economic individualism have focused on its effects on the economic information used by individuals when voting. These studies find that economic individualists believe they are largely responsible for their own economic outcomes, and thus refuse to credit or blame the incumbent government based on their personal economic situation (Feldman 1982, Schlozman and Verba 1979, Sniderman and Brody 1977). As a result, economic individualists tend to be sociotropic rather than pocketbook voters - but this does not tell us how economic individualism influences the relationship individuals perceive between election outcomes and their own personal finances. While economic individualists may not blame or credit the incumbent government for their personal economic well-being, they might still see a relationship between who holds political power and their own economic fortunes.

However, there is also evidence that economic individualists not only refuse to blame or credit others for their personal economic well-being, but also do not even attribute changes in their personal economic situation to larger social forces (Abramowitz et al. 1988, Feldman 1982, Kinder and Mebane 1983, Schlozman and Verba 1979, Sniderman and Brody 1977). Instead, economic individualists believe that personal circumstances and actions are the primary determinants of one's personal economic situation. In contrast, those that reject economic individualism (economic "non-individualists") do tend to see a relationship 
between their personal economic well-being and macroeconomic forces such as governmental economic policy. In terms of the model above, this suggests that $\pi_{L}=\pi_{R}=0$ for economic individualists, while these terms can be unequal and non-zero for those who reject economic individualism. Given this, we expect adherence to economic individualism to be an important factor in determining the extent to which election outcomes influence expectations for personal economic well-being. Favorable election outcomes will lead to greater optimism in expectations for economic non-individualists, while there will be no such relationship for economic individualists. We test this hypothesis empirically in the following section.

Testing whether adherence to economic individualism influences the relationship between election outcomes and personal economic expectations is not only important substantively, but also serves a valuable methodological purpose. Specifically, it allows us to address a couple of potential concerns with our empirical test.

One concern with a test using expectations for personal economic well-being is the influence of politically irrelevant concerns. Kramer (1983) argued that the apparent irrelevance of pocketbook concerns in determining vote choice was a statistical artifact, arising from the fact that changes in personal economic well-being are due to both a government-induced component (that influences vote choice), and an exogenous, politically irrelevant component (that does not). In any given cross-sectional survey, most variation in personal economic well-being will be due to this politically irrelevant component - thus, estimates of the political influence of pocketbook concerns are biased downward. Following this logic, the influence of the election outcome on personal economic expectations may similarly be swamped by personal economic factors irrelevant to our test (e.g., sending a child to college, receiving a raise), leading to a statistically insignificant relationship between election outcomes and expectations even if such a relationship exists. Thus, finding a null relationship between election outcomes and expectations may simply be due to our inability to separate the changes in 
personal economic well-being an individual expects due to the election from other concerns. However, there is little reason to believe that economic individualists would be more subject to non-political personal economic concerns than those who reject economic individualism. Thus, finding the hypothesized difference in the influence of election outcomes on expectations for personal economic well-being across adherence to economic individualism will give us confidence that any null relationship between election outcomes and expectations for economic individualists did not simply result from noisy measurement of personal economic expectations.

Another concern is that a relationship between election outcomes and expectations for personal economic well-being will exist in our survey data even if individuals do not believe that the election outcome matters for their personal economic fortunes. For instance, the fate of an individual's favored candidate or party in the election might create a general sense of optimism or pessimism that influences how the individual views his or her future personal finances, even if the individual does not perceive a relationship between the election outcome and his or her personal economic well-being. Similarly, individuals might report more optimistic (pessimistic) expectations when their favored candidate or party wins (loses) to make their attitudes consistent with past behavior (Anderson et al. 2004). Again, finding the hypothesized difference across adherence to economic individualism will help guard against these possibilities, as there is no reason to believe that those who reject economic individualism are more susceptible to these effects or other influences that might lead to a spurious relationship between election outcomes and expectations.

We further strengthen our claim regarding the influence of adherence to economic individualism in the development of personal economic expectations by exploring how the relationship between the election outcome and expectations for the national economy varies with economic individualism. The differences across economic individualism we hypothe- 
size in the relationship between election outcomes and expectations for personal economic well-being should not be apparent when we consider expectations for the national economy. Instead, we expect those who view the election outcome as favorable to have more optimistic expectations for the national economy than those that view the election outcome as unfavorable regardless of adherence to economic individualism. Finding this will help ensure there is no unobserved difference related to economic individualism in how individuals relate election outcomes to economic expectations (for instance, this would help rule out the possibility that those who reject economic individualism are more optimistic then economic individualists when their favored candidate wins).

\section{Empirical test}

We test whether election outcomes influence individual perceptions of personal economic well-being, and how this relationship is moderated by economic individualism. In order to do this we require post-election survey data that (1) was gathered at a time after the election when the final outcome of the election was known, (2) contained a measure of expectations for personal economic well-being, and (3) contained a measure of economic individualism, as well as significant variation across individuals in adherence to economic individualism. Unfortunately, there is a surprising lack of survey data that meets the above criteria. Many post-election surveys do not contain questions on economic expectations, perhaps because it is not obvious how such questions could be used in a model of voting behavior. Other datasets did not have much variation in adherence to economic individualism (particularly data from the U.S.) or were collected at a time when the final election outcome was unknown (such as the 2000 American National Election Study). We also wished to use a single survey for our test - additional variance in economic individualism could be obtained by pooling data 
across countries, but we would then contend with differences in question wording, question ordering, and language, among other things.

\subsection{Data and coding}

One dataset that was ideal for our purposes was the 1994 German Election Study (PostElection Study). This study consisted of a survey administered to 2046 respondents across Germany, with an oversample of East Germans, and contained all of the survey measures we required. The election took place on October 16, 1994. Interviews were conducted between October 17 and November 25 (the two interviews in the dataset coded as taking place before the election were discarded). The result of the 1994 election was a narrow victory for the incumbent parties (the Christian Democratic Union (CDU, the Christian Social Union (CSU) in Bavaria) and the Free Democratic Party (FDP)). The FDP and CDU/CSU had confirmed their intention to form the government again if the voters would allow it in June, so the government resulting from the October election was known to voters almost immediately after the polls closed (Roberts 1997, p. 165). Thus, individuals in our post-election survey were most likely aware of who would form the government at the time of the interview.

The presence of respondents from both East and West Germany in the sample represents a particular strength of this dataset. While West Germany was a capitalist society, East Germany was a socialist state until reunification with West Germany in $1989 .{ }^{4}$ Given the relationship between socialism and economic individualism (which we discuss below), this means we are likely to have much more variation in adherence to economic individualism in this data than in other datasets from single countries.

Our test examines the influence of the Bundestag (lower house) election outcome on expectations for personal economic well-being. The dependent variable in our test is individual 
expectations for personal economic well-being. The economic expectations question asked individuals to state whether they thought in one year's time their personal economic wellbeing would get much better, get better, stay the same, get worse, or get much worse. Due to the small numbers of respondents in the extreme categories, these categories were collapsed into the adjacent categories, meaning answers to these questions were coded on a three point scale (worse, same, better).

Seats in the Bundestag are filled in two ways - half are elected in plurality elections in single member districts, and half are elected in a proportional representation elections using party lists. The plurality vote is referred to as the first vote, while the PR vote is referred to as the second vote. Our measure of an individual's opinion of the election outcome is based on reported party choice for their second vote. ${ }^{5}$ If an individual voted for a party that became part of the government after the election (the CDU/CSU or FDP), we coded their perception of the election outcome as favorable. Similarly, if an individual voted for a party that became part of the opposition, we coded their perception of the election outcome as unfavorable. Using a survey question on recalled vote choice, we created a measure for an individual's perception of the election outcome, coded 1 for favorable outcomes, and 0 for unfavorable outcomes.

The measure of adherence to economic individualism that we use merits some explanation. There is a considerable body of research in political science, sociology, and social psychology on cultural and cross-national differences in norms and values that suggest that economic individualism is negatively related to socialism (Finifter 1996, Finifter and Mickiewicz 1992, Hofstede 1994, Mason 1995, Miller et al. 1994, 1996). As Miller et al. (1994, p. 400) note:

... [A] core element of socialist ideology involves the locus of responsibility for social well-being. ... Under socialist systems, the state has assumed the major 
role in caring for individual well-being.

This suggests that attitudes towards socialism are likely to be a good measure of adherence to economic individualism. Socialist ideals are in many ways the opposite of economic individualism. Thus, those that hold a positive attitude towards socialism are unlikely to also adhere to the ideals of economic individualism. In our empirical analysis we use attitudes towards socialism or the role of the state in providing for individuals as our measure of economic individualism. Survey respondents were asked (in German) if they agreed or disagreed with the statement: "Socialism is basically a good idea that has just been executed badly." ${ }^{6}$ We generate a dichotomous measure for rejection of economic individualism, with those respondents who agreed or strongly agreed with this statement coded as not ascribing to economic individualism (coded as a one), while those who disagreed or strongly disagreed were coded as economic individualists (coded as a zero).

We hypothesize that there will be a relationship between perceived election outcomes and expectations for those who reject economic individualism, while there will be no such relationship for economic individualists. Thus, we generate an interaction term between our measure of economic individualism and our measure of perceived favorable election outcome. This interaction term is expected to be positive, indicating that favorable election outcomes lead to greater optimism in expectations for personal economic well-being for economic nonindividualists as compared to economic individualists.

We include a set of control variables selected not only to rule out other influences on the formation of expectations for personal economic well-being, but also to address several potential concerns with our measure of economic individualism. One such concern is that our measure of economic individualism may simply serve as a proxy for party preference. That is, those who report favorable feelings towards socialism may also be much more likely to 
prefer one of the parties on the left that did not form the government (the Social Democrats, the Greens, or the PDS (post-Communists)) in comparison to those that did (the relatively free-market CDU/CSU and FDP). This concern is addressed in our model with the dummy variable on perceptions of the election outcome described above.

Another concern is that our measure may just capture differences between East and West Germans, as East Germans may have more favorable attitudes towards socialism than West Germans. This could compromise our hypothesis test, as there were significant differences in economic conditions between East and West Germany that may have affected expectations for personal economic well-being. We therefore include a dummy variable coded one if the interview took place in the former German Democratic Republic (East Germany), and zero if it took place in West Germany. In addition, as democratic elections were relatively new to East Germany, an interaction between perceptions of the election outcome and residence in the East was included to ensure that East and West Germans did not link election and economic outcomes in different ways. An interaction between residence in the East and our measure of economic individualism was also included to ensure there were no significant differences in how residents of the East and West related adherence to economic individualism to expectations for personal economic well-being.

A third concern is that our measure of economic individualism could actually be measuring an individual's social class, as working class respondents may be more likely to have a favorable view of socialism than middle or upper class respondents. Weatherford (1978) argues that those from lower social classes are more likely to link personal economic well-being to political preferences, as they are more likely to suffer ill effects in an economic downturn. Thus, we include a 5 point scale indicating the survey respondent's self perception of which social class he or she belongs to, with 1 indicating the lowest social class and 5 the highest. An interaction between social class and residence in the East was also included, due to ev- 
idence that social class has a different effect on voting behavior in East Germany than in West Germany (Dalton 1996, p.39).

A final concern is that past research has found that women tend to hold more collectivist attitudes than men, perhaps due to gender socialization (Gilligan 1982) or the relative economic vulnerability of women as compared to men (Piven 1985), which means our measure of economic individualism could also be picking up possible gender effects. Thus, we include a dummy variable coded one for females and zero for males to ensure any differences we observe in expectations for personal economic well-being are not due to the relative economic vulnerability of women.

Table 1 presents a comparison of our measure of economic individualism with the other possible determinants of attitudes towards socialism described above. Although some relationships are apparent (as we would expect if our measure is valid), this does not pose a problem for our analysis once we include the appropriate control variables.

\section{Table 1 here.}

We also control for several other variables that could influence the formation of expectations for personal economic well-being. Political sophistication can influence the formation of perceptions of one's personal economic situation (Gomez and Wilson 2001, Weatherford 1983), so we include education as a control for political sophistication. Education is coded as an 8 point scale, with higher numbers indicating higher levels of education. Household income in Deutsche Marks (divided by 10,000) was included to separate the effects of relative wealth on expectations from the influences we are studying. Older people tend to be more pessimistic in their expectations for personal economic well-being (Katona et al. 1971), so age in years was included as another control variable. It is also possible that members of 
households with union members will have different personal economic expectations than the population at large (due to better security of employment). Thus, we also include a dummy variable coded one if a member of the household is a member of a trade union and zero otherwise.

Finally, past research has found that retrospective economic perceptions play an important role in the formation of economic expectations (Conover at al. 1987, Haller and Norpoth 1994, Krause 1997). However, there is some concern that these retrospective economic evaluations are strongly influenced by political preferences (Anderson et al. 2004, DeBoef and Kellstedt 2004, Wlezien et al. 1997). If retrospective economic evaluations are a proxy for political preferences, then including these perceptions might mask the influence that perceptions of the election result are having on expectations for personal economic well-being. To guard against this possibility we present two models below; the first including all of the variables discussed above, and the second adding retrospective perceptions of personal economic well-being as an independent variable. This variable is coded -1 for individuals that felt their family's current personal economic situation was worse than it was one year ago, 0 if it was unchanged, and 1 if it was improved.

Individuals who did not provide a recalled vote choice (and thus a perception of the election outcome) were removed from the dataset. Multiple imputation was used to fill in the missing values for the remaining observations in the dataset. Unless the pattern of missing data is completely random across all variables listwise deletion will lead to biased parameter estimates. Therefore, we use a multiple imputation procedure to avoid potential problems with missing data (King et al. 2001, Little and Rubin 2002, Rubin 1987). We implemented the multiple imputation procedure as follows. First, a statistical model was used to create predictions for the distribution of each variable with missing data, conditional on all of the other information in the dataset. Then multiple imputations for each missing 
value were created, resulting in multiple datasets, each with the same values for the observed data and different imputations for the missing data. ${ }^{7}$ Five imputations were used for each missing value, which resulted in 1478 observations in each of the five imputed datasets. In the statistical analysis below each model was estimated on each imputed dataset and the results were combined, accounting for variation within each dataset as well as variation across the imputed datasets (see King et al. 2001, Schafer 1997).

\section{$3.2 \quad$ Results}

As expectations for personal economic well-being is coded as an ordered variable (better, same, worse), we use an ordered logit model to examine the influences on these expectations. Table 2 presents the results of two models of influences on post-election expectations for personal economic well-being; the first omits retrospective perceptions of personal finances, while the second includes them.

\section{Table 2 here.}

The results from Model 1 support our hypothesis that perceptions of the election outcome influenced the personal economic expectations of those who rejected economic individualism, while not having an effect on the expectations of economic individualists. While the coefficients for both a favorable perception of the election outcome and rejection of economic individualism were statistically insignificant, the coefficient on the interaction between these variables is positive and statistically significant. This indicates that a victory by an individual's favored candidate led to more optimism about future personal economic well-being for economic non-individualists, while it had no statistically significant effect for economic individualists. $^{8}$ 
Among the control variables, the interaction of our measure of economic individualism with residence in the East is negative and statistically significant, meaning that those who lived in the East and were not economic individualists were more pessimistic about their future personal finances than either those who lived in the West or those in the East who were economic individualists. Older respondents were more pessimistic in their expectations for their personal economic well-being, as noted in other studies (Katona et al. 1971). Finally, in Model 2 we see that positive retrospective perceptions of personal economic well-being led to more positive expectations. However, the most important result from Model 2 is that perceptions of the election outcome continue to have the hypothesized effect on expectations for personal economic well-being - a favorable election outcome leads to greater optimism for those who reject economic individualism, while it has no statistically significant effect for economic individualists.

As additional confirmation that our results were not driven by differences between East and West Germans in either the formation of economic expectations or interpretation of our measure of economic individualism, we divided our sample between East and West Germans, and between economic individualists and non-individualists. A replication of the model in Table 2 for each of these 4 subsamples produced the same substantive conclusions we reach above - the election outcome had no statistically significant influence on the expectations of both East and West German economic individualists, while it did have an influence on the expectations of both East and West Germans who rejected economic individualism. These results are presented in Table 3 .

\section{Table 3 here.}

Of course, ordered logit coefficients cannot be interpreted directly. In order to demonstrate how the influence of perceptions of the election outcome on expectations for personal 
economic well-being varied across adherence to economic individualism, we generated a hypothetical individual, with values of the independent variables set to their mean or modal values. ${ }^{9}$ Then, using the results from Table 2, we calculated the predicted probabilities for different expectations for this individual as we varied economic individualism and perceptions of the election outcome. The mean and standard deviation of the predicted probabilities were calculated using 1000 draws from the multivariate normal distribution of the estimated parameters (200 from each imputation), and then multiplied by 100 for ease of presentation. The results of these calculations are presented in Table 4. The four cells at the top left of the table present the predicted percentage of the time this hypothetical voter would expect his personal economic well-being to get better, stay the same, or get worse over the coming year for different combinations of election outcomes and adherence to economic individualism. The two leftmost cells in the bottom row present the difference in these predicted percentages if we switch this hypothetical individual from holding a unfavorable to an favorable opinion of the election outcome (switched from voting for a losing party to voting for a winning party in the previous election), while the two top cells in the rightmost column present the difference in these predicted percentages if we switch this hypothetical individual from an economic individualist to rejecting economic individualism. Finally, the bottom right cell presents the difference between the two leftmost cells in the bottom row (or the two top cells in the rightmost column) in the table, giving us the difference in the influence of perceptions of the election outcome on expectations for this hypothetical individual between acceptance and rejection of economic individualism.

\section{Table 4 here.}

If our hypothetical individual was not an economic individualist, he was more pessimistic in his expectations for personal economic well-being if he had an unfavorable view of the 
election outcome than if he had a favorable view of the election outcome. In contrast, the expectations for this hypothetical individual if he were an economic individualist show almost no variation across perceptions of the election outcome. The last row reveals that perceptions of the election outcome had a statistically significant effect on expectations if our hypothetical individual rejected economic individualism, while the effect was statistically insignificant if he was an economic individualist. Further, the bottom right cell reveals there is a statistically significant difference in the influence of perceptions of the election outcome on the expectations of this hypothetical individual between accepting or rejecting economic individualism. This confirms that perceptions of the election outcome do influence expectations for personal economic well-being for those who reject economic individualism, while not influencing the expectations of economic individualists.

Finally, a useful check of our results is to consider expectations for the national economy. It is possible that economic non-individualists who had a favorable view of the election outcome may have been more optimistic in general than other individuals for some unobserved reason. We can test this alternative explanation by noting that our hypothesis does not predict that these individuals would be more optimistic in their expectations for the economy as a whole. However, if this alternative explanation is correct, then individuals who reject economic individualism and had a favorable view of the election outcome should also be more optimistic in their expectations for the national economy.

To rule out this alternative explanation we estimate two models similar to those presented in Table 2. The dependent variable is expectations for the state of the national economy in one year's time, coded -1 if individuals felt the state of the national economy would grow worse in one year's time, 0 if they felt it would stay the same, and 1 if they thought it would improve. Model 1 below uses the same independent variables as Model 1 in Table 2, and adds expectations for personal economic well-being. Past research has found that expectations 
for the national economy are often influenced by expectations for personal economic wellbeing (Conover et al. 1987, Duch et al. 2000, Krause 1997). Model 2 adds retrospective perceptions of the state of the national economy, coded -1 for individuals that felt the state of the national economy was worse than it was one year ago, 0 if it was unchanged, and 1 if it was improved. The results of estimating these models are presented in Table 5.

\section{Table 5 here.}

The coefficient for the interaction between rejection of economic individualism and perceptions of the election outcome is statistically insignificant. This demonstrates that those who rejected economic individualism and who had a favorable perception of the election outcome were no more optimistic in their expectations for the economy as a whole than others, lending further support to our hypothesis. Instead, a victory by an individual's favored candidate had a positive and statistically significant influence on expectations for the state of the national economy regardless of adherence to economic individualism in Model 1, a finding consistent with that of Anderson et al. (2004). This effect was statistically insignificant in Model 2, possibly due to collinearity resulting from the close relationship between retrospective economic perceptions and political preferences (Anderson et al. 2004, DeBoef and Kellstedt 2004, Wlezien et al. 1997).

Overall, these results reveal that both economic individualists and economic non-individualists believe that an election victory by their preferred party will improve the future state of the national economy, but only economic non-individualists perceive a relationship between the election outcome and the future state of their personal economic well-being. 


\section{Conclusion}

Despite a vast literature examining the links between economics and politics, the relationship individuals perceive between elections and their personal economic well-being has gone largely unexplored. This paper addresses this gap in the literature, testing whether individuals believe that an election victory by their favored candidate will improve their personal economic well-being. We adopt a new approach to explore this relationship by examining the relationship between vote choice, the election outcome, and post-election expectations for personal economic well-being. We find that economic individualism plays an important role in shaping the relationship individuals perceive between election outcomes and their personal economic well-being. Individuals who reject economic individualism do perceive a relationship, with those viewing an election outcome as favorable having more optimistic personal economic expectations than those who view the election outcome as unfavorable. Conversely, election outcomes do not influence the expectations of economic individualists. Our confidence in the relationship we discover between election outcomes and post-election expectations is strengthened by our ability to find this ex ante hypothesized difference in perceptions across adherence to economic individualism. The fact that expectations for the national economy did not differ by economic individualism also adds to our confidence.

Our study also contributes to our growing understanding of how political events help shape economic perceptions. Previous studies generally focus on perceptions of macroeconomic indicators or the economy as a whole. Here we find that election results are an important influence on expectations for personal economic well-being for those individuals who reject economic individualism. Further, this study extends our understanding of how economic individualism shapes the relationship between economics and politics. Previous studies of economic individualism demonstrate its effects on attributions of responsibility for 
economic conditions when voting. Here we demonstrate that economic individualism is also an influence on the formation of economic perceptions and beliefs concerning the effect of policymakers on personal economic welfare.

Finally, the research methods we present here may help reveal the economic motives behind a vote choice, a long-standing and difficult theoretical puzzle. Although self-interest has long been held to be a powerful motive for political behavior (Mansbridge 1990, Monroe 1991), there is little clear evidence that economic self-interest plays a role in determining voting behavior. Our method of examining the relationship between perceptions of election outcomes and post-election expectations for personal economic well-being may help address this problem. If individuals are pursuing their economic self-interest through their vote choice, then their expectations for personal economic well-being should be more optimistic when the election outcome is favorable than when it is unfavorable. Similarly, if there is no relationship between post-election expectations for personal economic well-being and vote choice, this suggests that individuals are not pursuing their economic self-interest through their vote. These observations do not allow us to perfectly determine the economic motive behind a vote choice - for instance, we might still see a relationship between perceptions of the election outcome and post-election personal economic expectations even if people are not pursuing their economic self-interest through their vote. However, further empirical tests based on our observations could allow us to shed some light on a question that has stood unanswered for decades. We leave this to future research. 


\section{Notes}

${ }^{1}$ Although defining "victory" is difficult in some electoral systems, we will regard any election outcome that results in at least some share of governing power for an individual's favored candidate an election victory.

${ }^{2}$ Note that in order for individuals to incorporate the election outcome into their subsequent expectations for personal economic well-being, they cannot form these expectations by simply extrapolating the past into the future. Instead, individuals must be able to anticipate how the election result will affect their future economic well-being. Although there is some debate on the precise mechanism through which individuals form their economic forecasts and the relationship of these forecasts to political evaluations, most studies on the subject find that individuals do seem to incorporate new political information into their economic expectations (Conover et al. 1987, DeBoef and Kellstedt 2004, Haller and Norpoth 1994, MacKuen et al. 1992).

${ }^{3}$ One possible exception to this could be a "halo effect", where individuals falsely report voting for the election winner. This does not appear to be a problem in our empirical test below, as reported vote totals in the survey match the actual vote fairly closely.

${ }^{4} \mathrm{~A}$ possible point of concern with this data is that due to the economic experience of living in a Communist country, East Germans may evaluate their personal economic well-being differently than West Germans, complicating the test of our hypothesis. However, Nannestad et al. (2003) reveal that individuals who move from a communist system to a market system quickly adjust to evaluate economic conditions in the same way as those who have always lived in a market system, and Anderson and O'Connor (2000) show that by 1993 East Germans were evaluating economic conditions in the same way as West Germans.

${ }^{5}$ Results using the first vote were substantively identical to those presented below.

${ }^{6}$ A potential concern with this survey measure is its "double-barreled" nature, where individuals could possibly evaluate both the inherent merits of socialism and its execution in practice. While respondents that agree with this statement clearly had favorable attitudes towards socialism, those who disagree may potentially have had favorable attitudes towards socialism, but disagreed with the contention that socialism was "executed badly". However, given the poor state of the economy in East Germany under communist 
rule (which was especially apparent after reunification), we are confident that few individuals would feel socialism was a good idea that was executed well in East Germany.

${ }^{7}$ Amelia was used to perform the multiple imputations (Honaker et al. 2001). All variables used in the empirical analysis were included in the imputation model, as well as retrospective and prospective measures of the East and West German economies, three opinion questions on relations between East and West Germany, dummy variables for the unemployed and retired, and a measure of media exposure. Most missing data was on income, social class, and level of education, and no problematic patterns in the missing data were observed (such as differences between East and West Germans). A replication of the model in Table 2 using listwise deletion was substantively similar, although there were only 563 observations, and the interaction between economic individualism and perceptions of the election outcome was only significant at the $p<0.10$ level.

${ }^{8}$ Note that these findings also strengthen our confidence in our measure of economic individualism. While our theory predicts that the influence of the election outcome on expectations for personal economic wellbeing will vary according to economic individualism, we are unaware of any theory that would predict the same kind of variation for the other possible determinants of attitudes towards socialism discussed above. This, combined with the theoretical literature that predicts a negative relationship between adherence to economic individualism and adherence to socialist ideals, the control variables in our model, and descriptive statistics that reveal our measure is not a proxy for some other determinant of attitudes towards socialism, give us confidence in our measurement strategy.

${ }^{9}$ This hypothetical individual was male and 50 years old, lived in the West, felt his personal finances had improved over the last year, was not from a union household, and was of mean income, social class, and education. 


\section{References}

Abramowitz, Alan I., David J. Lanoue, and Subha Ramesh. 1988. "Economic Conditions, Causal Attributions, and Political Evaluations in the 1984 Presidential Election." Journal of Politics 50:848-863.

Alesina, Alberto, and Howard Rosenthal. 1995. Partisan Politics, Divided Government, and the Economy. Cambridge: Cambridge University Press.

Anderson, Christopher J., Silvia M. Mendes, and Yuliya V. Tverdova. 2004. "Endogenous Economic Voting: Evidence from the 1997 British Election." Electoral Studies, forthcoming.

Anderson, Christopher J., and Kathleen M. O'Connor. 2000. "System Change, Learning and public Opinion about the Economy." British Journal of Political Science 30:147-172.

Conover, Pamela J., Stanley Feldman, and Kathleen Knight. 1986. "Judging Inflation and Unemployment: The Origins of Retrospective Evaluations." Journal of Politics 48:565-588.

Conover, Pamela J., Stanley Feldman, and Kathleen Knight. 1987. "The Personal and Political Underpinnings of Economic Forecasts." American Journal of Political Science 31:559583.

Dalton, Russell J. 1996. "A Divided Electorate?" In Gordon Smith, William E. Patterson, and Stephen Padgett (eds.), Developments in German Politics 2, pp. 35-54. Durham, NC: Duke University Press.

DeBoef, Suzanna, and Paul M. Kellstedt. 2004. "The Political (and Economic) Origins of Consumer Confidence." American Political Science Review, forthcoming.

Duch, Raymond M., Harvey D. Palmer, and Christopher J. Anderson. 2000. "Heterogeneity 
in Perceptions of National Economic Conditions." American Journal of Political Science 44:635-652.

Feldman, Stanley. 1982. "Economic Self-Interest and Political Behavior." American Journal of Political Science 26:446-466.

Finifter, Ada W. 1996. "Attitudes Toward Individual Responsibility and Political Reform in the Former Soviet Union." American Political Science Review 90:138-152.

Finifter, Ada W., and Ellen Mickiewicz. 1992. "Redefining the Political System of the USSR: Mass Support for Political Change." American Political Science Review 86:857-874.

Gilligan, Carol. 1982. In a Different Voice. Cambridge: Harvard University Press.

Gomez, Brad T., and J. Matthew Wilson. 2001. "Political Sophistication and Economic Voting in the American Electorate: A Theory of Heterogeneous Attribution." American Journal of Political Science 45:899-914.

Haller, H. Brandon, and Helmut Norpoth. 1994. "Let the Good Times Roll: The Economic Expectations of U.S. Voters." American Journal of Political Science, 38:625-650.

Haller, H. Brandon, and Helmut Norpoth. 1997. "Reality Bites: News Exposure and Economic Opinion." Public Opinion Quarterly, 61:555-575.

Hetherington, Mark J. 1996. "The Media's Role in Forming Voters' National Economic Evaluations in 1992." American Journal of Political Science 40:372-395.

Hofstede, Geert. 1984. Culture's Consequences: International Differences in Work-Related Values. Beverly Hills, CA: Sage Publications.

Honaker, James, Anne Joseph, Gary King, and Kenneth Scheve. 2001. Amelia: A Program 
for Missing Data (Gauss version). Cambridge, MA: Harvard University, http://GKing.Harvard.edu/.

Katona, George, Burkhard Strumpel, and Ernest Zahn. 1971. Aspirations and Affluence. New York: McGraw-Hill.

Kiewiet, D. Roderick. 1983. Macroeconomics and Micropolitics: The Electoral Effects of Economic Issues. Chicago, IL: The University of Chicago Press.

Kinder, Donald R., and D. Roderick Kiewiet. 1981. "Sociotropic Politics: The American Case." British Journal of Political Science 11:129-162.

Kinder, Donald R., and Walter R. Mebane. 1983. "Politics and Economics in Everyday Life." In K.R. Monroe (ed.), The Political Process and Economic Change. New York: Agathon.

King, Gary, James Honaker, Anne Joseph, and Kenneth Scheve. 2001. "Analyzing Incomplete Political Science Data: An Alternative Algorithm for Multiple Imputation." American Political Science Review 95:49-69.

Kramer, Gerald H. 1983. "The Ecological Fallacy Revisited: Aggregate- versus Individuallevel Findings on Economics and Elections, and Sociotropic Voting." American Political Science Review 77:92-111.

Krause, George A. 1997. "Voters, Information Heterogeneity, and the Dynamics of Aggregate Economic Expectations." American Journal of Political Science 41:1170-1200.

Lewis-Beck, Michael S. 1988. Economics and Elections. Ann Arbor, MI: University of Michigan Press.

Lewis-Beck, Michael S., and Martin Paldam. 2000. "Economic Voting: An Introduction." Electoral Studies 19:113-121. 
Little, Roderick J.A., and Donald Rubin. 2002. Statistical Analysis with Missing Data, 2nd ed. New York: Wiley.

MacKuen, Michael B., Robert S. Erikson, and James A. Stimson. 1992. "Peasants or Bankers? The American Electorate and the U.S. Economy." The American Political Science Review 86:597-611.

Mansbridge, Jane J. 1990. Beyond Self Interest. Chicago: University of Chicago Press.

Mason, David S. 1995. "Attitudes Toward the Market and Political Participation in the Postcommunist States." Slavic Review 54:385-406.

Miller, Arthur H., Vicki L. Hesli, and William M. Reisinger. 1994. "Reassessing Mass Support for Political Change in the Former USSR." American Political Science Review 88:399411.

Miller, Arthur H., William M. Reisinger, and Vicki L. Hesli. 1996. "Understanding Political Change in Post-Soviet Societies: A Further Commentary on Finifter and Mickiewicz." American Political Science Review 90:153-166.

Monroe, Kristen R., ed.. 1991. The Economic Approach to Politics. New York: Harper Collins.

Nannestad, Peter, Martin Paldam, and Michael Rosholm. 2003. "System Change and Economic Evaluations: A Study of Immigrants and Natives in Israel." Electoral Studies 22:485-501.

Norpoth, Helmut, Michael S. Lewis-Beck, and Jean-Dominique Lafay (eds.). 1991. Economics and Politics: The Calculus of Support. Ann Arbor: University of Michigan Press. 
Palmer, Harvey D., and Raymond M. Duch. 2001. "Do Surveys Provide Representative or Whimsical Assessments of the Economy?" Political Analysis 9:58-77.

Piven, Frances F. 1985. "Women and the State: Ideology, Power, and the Welfare State." In Gender and the Life Course, Alice S. Rossi, ed. New York: Aldine.

Roberts, Geoffrey K. 1997. Party Politics in the New Germany. London: Pinter.

Rubin, Donald. 1987. Multiple Imputation for Nonresponse in Surveys. New York: Wiley.

Schafer, Joseph L. 1997. Analysis of Incomplete Multivariate Data. New York: Chapman and Hall.

Schlozman, Kay L., and Sidney Verba. 1979. Injury to Insult. Cambridge, MA: Harvard University Press.

Sears, David O., and Richard R. Lau. 1983. "Inducing Apparently Self-Interested Political Preferences." American Journal of Political Science 27:222-252.

Sniderman, Paul M. and Richard A. Brody. 1977. "Coping: the Ethic of Self-Reliance." American Journal of Political Science, 21:501-521.

Weatherford, Stephen M. 1978. "Economic Conditions and Electoral Outcomes: Class Differences in the Political Response to Recession." American Journal of Political Science 22:917-938.

Weatherford, Stephen M. 1983. "Economic Voting and the 'Symbolic Politics' Argument: A Reinterpretation and Synthesis." American Political Science Review 77:158-174.

Wlezien, Christopher, Mark Franklin, and Daniel Twiggs. 1997. "Economic Perceptions and Vote Choice: Disentangling the Endogeneity." Political Behavior 19:7-17. 
Table 1: Comparison of Measure of Economic Individualism with Other Possible Determinants of Attitudes Towards Socialism

\begin{tabular}{l|cc}
\hline \hline & $\begin{array}{c}\text { Economic } \\
\text { Individualists }\end{array}$ & $\begin{array}{c}\text { Economic } \\
\text { Non-Individualists }\end{array}$ \\
\hline Party Preference & $56.1(299)$ & $38.9(241)$ \\
Right & $43.9(234)$ & $68.1(514)$ \\
Left & & \\
Residence & $40.2(283)$ & $62.5(659)$ \\
East & $59.8(421)$ & $37.5(395)$ \\
West & & \\
Social Class & $4.2(26)$ & $6.3(56)$ \\
Lowest & $29.7(183)$ & $33.5(296)$ \\
Low-Middle & $53.7(331)$ & $50.7(449)$ \\
Middle & $12.0(74)$ & $8.4(74)$ \\
High-Middle & $0.5(3)$ & $1.1(10)$ \\
Highest & & \\
Gender & $49.4(348)$ & $49.4(521)$ \\
Male & $50.6(356)$ & $50.6(533)$ \\
Female & &
\end{tabular}

Notes: Entries are column percentages, with frequencies in parentheses. Number of observations differs across comparisons due to missing data. 
Table 2: Influences on Expectations for Personal Economic Well-Being: 1994 German Bundestag Election

\begin{tabular}{|c|c|c|}
\hline Independent Variables & Model 1 & Model 2 \\
\hline Favorable Election Outcome & $\begin{array}{c}0.08 \\
(0.19)\end{array}$ & $\begin{array}{c}0.02 \\
(0.19)\end{array}$ \\
\hline Rejects Economic Individualism & $\begin{array}{l}-0.29 \\
(0.19)\end{array}$ & $\begin{array}{l}-0.24 \\
(0.19)\end{array}$ \\
\hline Rejects Ec. Ind. $\times$ Fav. Outcome & $\begin{array}{l}0.53^{*} \\
(0.23)\end{array}$ & $\begin{array}{l}0.50^{*} \\
(0.24)\end{array}$ \\
\hline Lives in East & $\begin{array}{c}0.33 \\
(0.48)\end{array}$ & $\begin{array}{c}0.27 \\
(0.48)\end{array}$ \\
\hline East $\times$ Fav. Outcome & $\begin{array}{l}-0.01 \\
(0.23)\end{array}$ & $\begin{array}{c}0.01 \\
(0.23)\end{array}$ \\
\hline East $\times$ Rejects Ec. Ind. & $\begin{array}{l}-0.62^{*} \\
(0.25)\end{array}$ & $\begin{array}{l}-0.61^{*} \\
(0.25)\end{array}$ \\
\hline Social Class & $\begin{array}{l}-0.11 \\
(0.12)\end{array}$ & $\begin{array}{l}-0.18 \\
(0.11)\end{array}$ \\
\hline East $\times$ Social Class & $\begin{array}{c}0.15 \\
(0.15)\end{array}$ & $\begin{array}{c}0.17 \\
(0.15)\end{array}$ \\
\hline Female & $\begin{array}{l}-0.13 \\
(0.13)\end{array}$ & $\begin{array}{l}-0.13 \\
(0.13)\end{array}$ \\
\hline Education & $\begin{array}{c}0.04 \\
(0.04)\end{array}$ & $\begin{array}{c}0.04 \\
(0.04)\end{array}$ \\
\hline Income & $\begin{array}{l}-0.52 \\
(0.62)\end{array}$ & $\begin{array}{l}-0.62 \\
(0.62)\end{array}$ \\
\hline Age & $\begin{array}{c}-0.02^{* *} \\
(0.00)\end{array}$ & $\begin{array}{c}-0.02^{* *} \\
(0.00)\end{array}$ \\
\hline Union Household & $\begin{array}{l}-0.06 \\
(0.14)\end{array}$ & $\begin{array}{l}-0.09 \\
(0.13)\end{array}$ \\
\hline Ret. Personal Finances & & $\begin{array}{c}0.31^{* *} \\
(0.08)\end{array}$ \\
\hline$\tau_{1}$ & $\begin{array}{l}-3.60 \\
(0.48)\end{array}$ & $\begin{array}{l}-3.78 \\
(0.48)\end{array}$ \\
\hline$\tau_{2}$ & $\begin{array}{l}-0.23 \\
(0.45)\end{array}$ & $\begin{array}{l}-0.37 \\
(0.45)\end{array}$ \\
\hline $\begin{array}{l}\text { LR } \chi^{2} \text { for Model Fit } \\
\text { Number of Observations }\end{array}$ & $\begin{array}{c}90.26^{* *} \\
1478\end{array}$ & $\begin{array}{c}105.50^{* *} \\
1478\end{array}$ \\
\hline
\end{tabular}

Notes: Standard errors in parentheses. * indicates statistical significance at the $p<0.05$ level, ${ }^{* *}$ indicates significance at the $p<0.01$ level. The dependent variable is a three point scale for expectations for personal economic well-being (worse, same, better), with higher numbers indicating more positive expectations. 


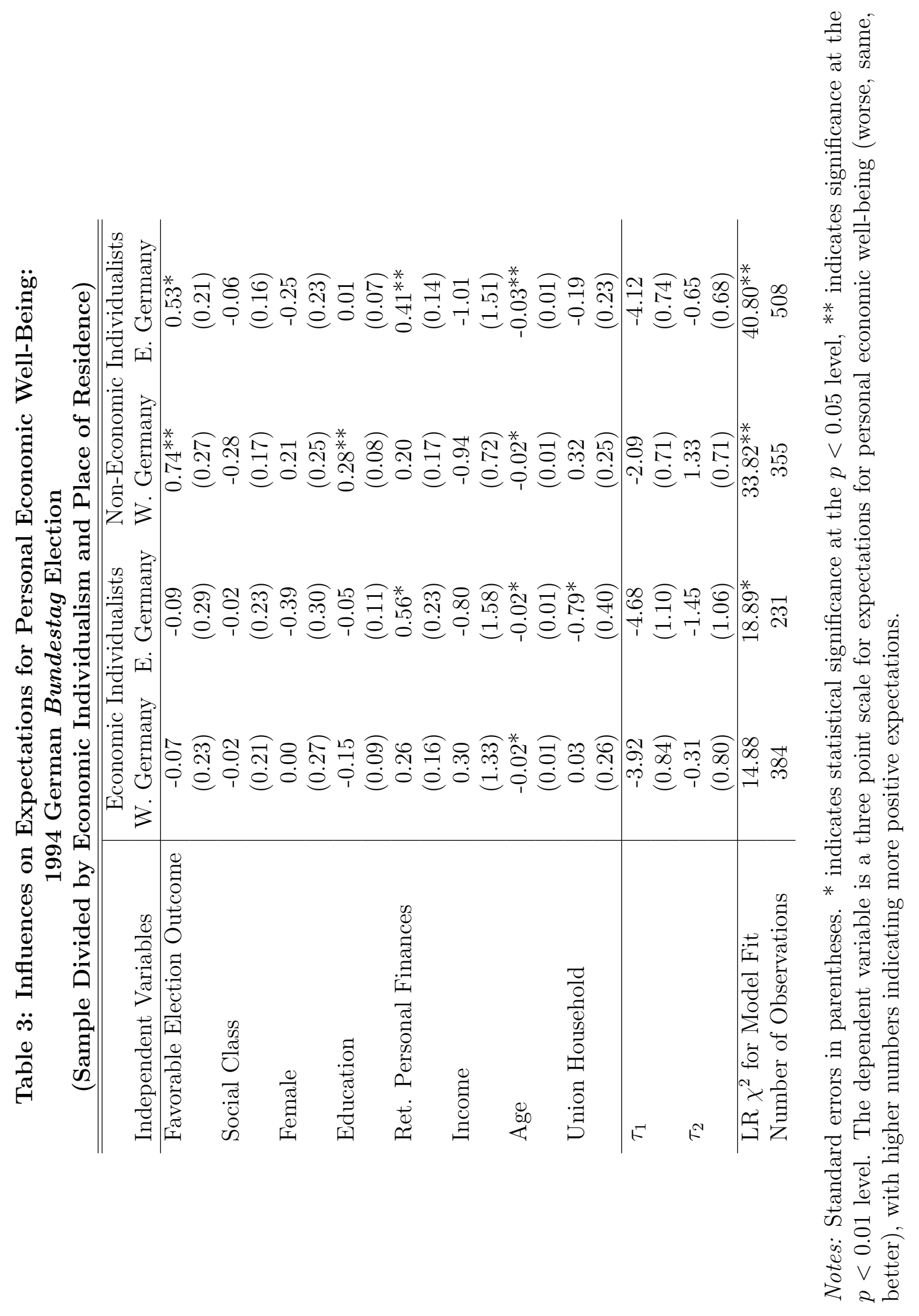




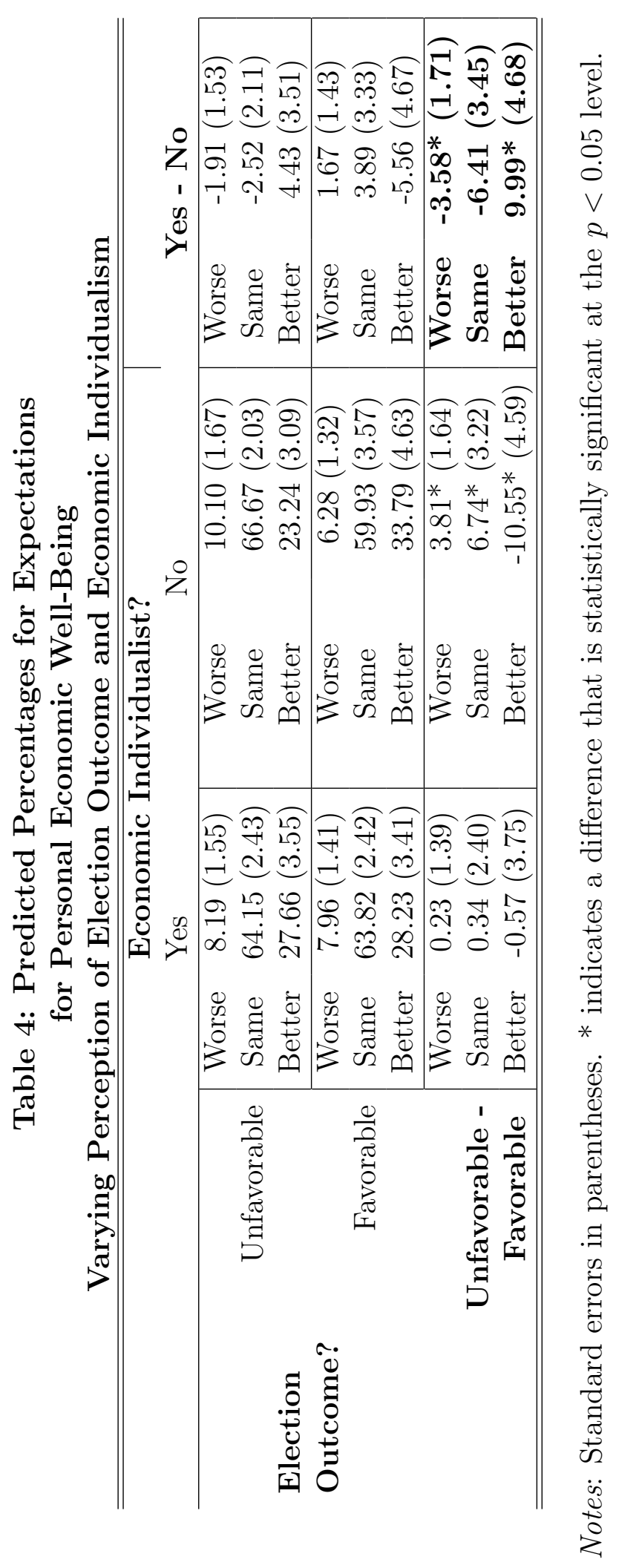


Table 5: Influences on Expectations for National Economy: 1994 German Bundestag Election

\begin{tabular}{|c|c|c|}
\hline Independent Variables & Model 1 & Model 2 \\
\hline Favorable Election Outcome & $\begin{array}{l}0.48^{*} \\
(0.20)\end{array}$ & $\begin{array}{c}0.33 \\
(0.20)\end{array}$ \\
\hline Rejects Economic Individualism & $\begin{array}{c}-0.69^{* *} \\
(0.20)\end{array}$ & $\begin{array}{c}-0.66^{* *} \\
(0.20)\end{array}$ \\
\hline Rejects Ec. Ind. $\times$ Fav. Outcome & $\begin{array}{c}0.03 \\
(0.25)\end{array}$ & $\begin{array}{l}0.07 \\
(0.26)\end{array}$ \\
\hline Lives in East & $\begin{array}{c}0.01 \\
(0.47)\end{array}$ & $\begin{array}{l}-0.07 \\
(0.47)\end{array}$ \\
\hline East $\times$ Fav. Outcome & $\begin{array}{l}-0.17 \\
(0.24)\end{array}$ & $\begin{array}{l}-0.15 \\
(0.24)\end{array}$ \\
\hline East $\times$ Rejects Ec. Ind. & $\begin{array}{c}0.37 \\
(0.26)\end{array}$ & $\begin{array}{c}0.32 \\
(0.26)\end{array}$ \\
\hline Social Class & $\begin{array}{c}0.13 \\
(0.11)\end{array}$ & $\begin{array}{l}0.07 \\
(0.11)\end{array}$ \\
\hline East $\times$ Social Class & $\begin{array}{c}0.09 \\
(0.15)\end{array}$ & $\begin{array}{c}0.11 \\
(0.15)\end{array}$ \\
\hline Female & $\begin{array}{l}-0.22 \\
(0.12)\end{array}$ & $\begin{array}{l}-0.17 \\
(0.12)\end{array}$ \\
\hline Education & $\begin{array}{l}0.10^{*} \\
(0.04)\end{array}$ & $\begin{array}{l}0.10^{*} \\
(0.04)\end{array}$ \\
\hline Income & $\begin{array}{c}0.09 \\
(0.57)\end{array}$ & $\begin{array}{c}0.21 \\
(0.59)\end{array}$ \\
\hline Age & $\begin{array}{c}0.00 \\
(0.00)\end{array}$ & $\begin{array}{c}0.00 \\
(0.00)\end{array}$ \\
\hline Union Household & $\begin{array}{l}-0.03 \\
(0.13)\end{array}$ & $\begin{array}{l}-0.03 \\
(0.14)\end{array}$ \\
\hline Exp. Personal Well-Being & $\begin{array}{l}1.84^{* *} \\
(0.11)\end{array}$ & $\begin{array}{c}1.78^{* *} \\
(0.11)\end{array}$ \\
\hline Ret. National Economy & & $\begin{array}{c}0.51^{* *} \\
(0.09)\end{array}$ \\
\hline$\tau_{1}$ & $\begin{array}{l}-1.75 \\
(0.45)\end{array}$ & $\begin{array}{l}-1.90 \\
(0.46)\end{array}$ \\
\hline$\tau_{2}$ & $\begin{array}{l}1.72 \\
(0.45)\end{array}$ & $\begin{array}{l}1.63 \\
(0.46)\end{array}$ \\
\hline $\begin{array}{l}\text { LR } \chi^{2} \text { for Model Fit } \\
\text { Number of Observations }\end{array}$ & $\begin{array}{c}426.56^{* *} \\
1478\end{array}$ & $\begin{array}{c}457.16^{* *} \\
1478\end{array}$ \\
\hline
\end{tabular}

Notes: Standard errors in parentheses. * indicates statistical significance at the $p<0.05$ level, ${ }^{* *}$ indicates significance at the $p<0.01$ level. The dependent variable is a three point scale for expectations for national economic conditions (worse, same, better), with higher numbers indicating more positive expectations. 